\title{
DEVELOPMENT OF LCDS-BASED INTERACTIVE ELECTRONIC SCHOOL BOOK ON BLACKBODY RADIATION AS SELF-INSTRUCTIONAL MATERIALS FOR FOSTERING STUDENT'S CRITICAL THINKING
}

\author{
Meta Dwi Ayuningtias ${ }^{1}$, Agus Suyatna ${ }^{2 *}$, Eko Suyanto ${ }^{3}$, Legborsi Nwineh ${ }^{4}$ \\ 1, 2, 3 Physics Education Department, Universitas Lampung. Jl. Prof. Dr. Soemantri Brojonegoro No. 1, \\ Bandar Lampung, Indonesia \\ ${ }^{4}$ Department of Vocational and Technology Education, Rivers State University, Port Harcourt, Nigeria \\ *Corresponding address: asuyatna@yahoo.com
}

Received: May $10^{\text {th }}, 2018$. Accepted: October $9^{\text {th }}, 2018$. Published: October $28^{\text {th }}, 2018$

\begin{abstract}
This study aims to develop an LCDS- based the interactive electronic school book on blackbody radiation that is valid as self-instructional materials to foster students' critical thinking skills. The method used was research and development. The stages of the research were determining the existing potentials and problems, information gathering, product design, product validation, the final revision of the product, and feasibility tests and practicality of operation. The research instrument used was a questionnaire. Interactive electronic school book has supporting contents, namely user manual, user learning process, video, animation, simulations, and interactive tests. Expert test for product consists of content validation with the score of 3,36 (very appropriate) and design validation with the score of 3,45 (very appropriate). Readability of LCDS- based interactive electronic school book on blackbody radiation got the score of 3 , 23 which belongs to the good quality. The practicality aspects got a score of 3.28 which means it can be operated independently.
\end{abstract}

(C) 2018 Physics Education, UIN Raden Intan, Lampung, Indonesia.

Keywords: critical thinking, electronic school book, interactive, LCDS, self-instructional materials

\section{INTRODUCTION}

Currently, education in Indonesia has implemented the new 2013 curriculum that is expected to improve education in Indonesia for the better. The 2013 curriculum also implements scientific approaches in various subjects (Depdikbud, 2013). So, students are required to have the ability to think critically in solving all problems in life. Critical thinking is convergent thinking, the process of assessing the validity or value of an emerging thing and executing by applying the principles (Alter, 2009). Critical thinking as a high-level thinking activity requires a set of cognitive skills (Baker \& Pomeroy, 2001). Critical thinking skills can help students to learn and adapt to all forms of change that take place over time (Ongardwanich,
Kanjanawasee, \& Tuipae, 2015). Practicing thinker is a stage of critical thinking development, they have enough skill in thinking to critique their own plan for systematic practice, and to construct a realistic critique of their powers of thought to solve the contextual problem (Mutakinati, Anwari, \& Yoshisuke, 2018). To deal with learning in the $21^{\text {st }}$ century, everyone must have critical thinking skills, digital literacy knowledge and skills, information literacy, media literacy, and master information and communication technologies (Jagodzin \& Wolski, 2015).

The students' critical thinking ability is predicted to be improved by using instructional media that provoke students' creative and innovative thinking. The use of Information Technology (IT) as a 
learning medium is already a demand. Although the design of IT-based media (Information Technology) requires special skills, it does not mean that media is avoided and abandoned. IT-based learning media can be internet, intranet, mobile phone, and CD Room / Flash Disk. Learning media based on interactive information technology makes learning more interesting and can visualize or describe abstract material by using the animation media in accordance with the situation in the field. Learning media use of three-dimensional (3D) virtual can make users more involved in the interaction, and gender will not influence how involved students are toward the interactivity but experience and spatial ability would (Yilmaz, Baydas, Karakus, $\&$ Goktas, 2015). Interactive multimedia used in learning is an excellent medium to improve the learning process by providing opportunities for students to develop skills, identify problems, organize, analyze, evaluate, and communicate information (Wiyono K., Liliasari, Setiawan, A., Paulus, 2012).

Creating electronic books can be done using electronic book software. Microsoft provides LCDS for free that allows creating high-quality learning content, interactive and accessible online. LCDS have a lot of excellent content such as simulation, video, moving animation, law, and theory and there are also interactive quizzes. The cooperative-based learning set assisted with animation media is proper and can be used to enhance students' learning outcome (Mahbub, Kirana, \& Poedjiastoeti, 2016). The profile of developing multimedia-based audio-video experiment has an interesting display, harmonious facilities, systematic and practical in used as well as become a solution of the practicum that not mastered yet (Rante, Sudarto, \& Ihsan, 2013). It is therefore recommended that teaching and Learning with technologies such as computer simulators. The utilization of computer simulation in the instruction was either carried out outside of Nigeria or not in the area of electrical installation is recommended (Nwineh \& Okwelle, 2018).

Physics is one branch of natural science that is closely related to everyday life. However, many students consider physics subject matter is very difficult because the physics subject matter not only deals with something that can be observed but also something abstract like in the material of blackbody radiation. As already known, physics is a science learning category that requires experimental activities to understand the concepts or principles. In addition to increasing critical thinking skill, it also increases students' learning achievement, because the students independently learn to get the results of the experiment which they do to prove a theory. This process can help students develop their knowledge because of the conduct the experiment by themselves which is later perfected by the teacher's explanation (Wartono, Hudha, \& Batlolona, 2018). For that, it is required tools or media such as electronic books that can visualize or illustrate the concept and improve students' critical thinking skills according to the demands of the 2013 curriculum.

Result of questionnaire of students' need to be obtained through electronic book criterion desired by student, 33,3\% student wanted it to contain description of physics material along with video showing phenomenon, $18,2 \%$ student wanted it to load simulation of practicum that can be done independently, 66,7\% student wanted it to load interactive exercise questions with feedback for exam exercises and college entrance preparation, and $6,1 \%$ of students wanted it to be operated independently or in groups. This is in accordance with the teacher's opinion in the questionnaire filled by the teacher. 
Based on the explanation above, the development of the LCDS-based interactive electronic school book on blackbody radiation as self-instructional materials to foster students' critical thinking skills was indispensable. The purpose of this research is the development of a valid LCDS-based interactive electronic school book on blackbody radiation as self-instructional materials to foster students' critical thinking skills and also knowing the feasibility and practicality of operation of this book.

\section{METHOD}

The method used was research and development method. Development undertaken was the development of an interactive electronic school book on black-body radiation material for the twelfth-grade students. The developed interactive electronic school books can be used independently by students or with teacher guidance.

As a first step to obtain the aspects to be studied, the distribution of needs analysis questionnaires was carried out. This needs analysis was carried out through questionnaire distribution techniques to teachers and students. The needs questionnaire was given to the twelfth-grade physics teachers and students at Public Senior High School Sixteen Bandar Lampung. The results of this questionnaire analysis were used to find out the expected product by teachers and students.

Design research in the development referred to Sugiyono's opinion (Sugiyono, 2011). Stages used in the study was only up to stage 6 which is the feasibility test and practicality of operation because the conditions in the field were not possible to be carried out until the dissemination. The procedure or research stages of product development are shown in Figure 1.

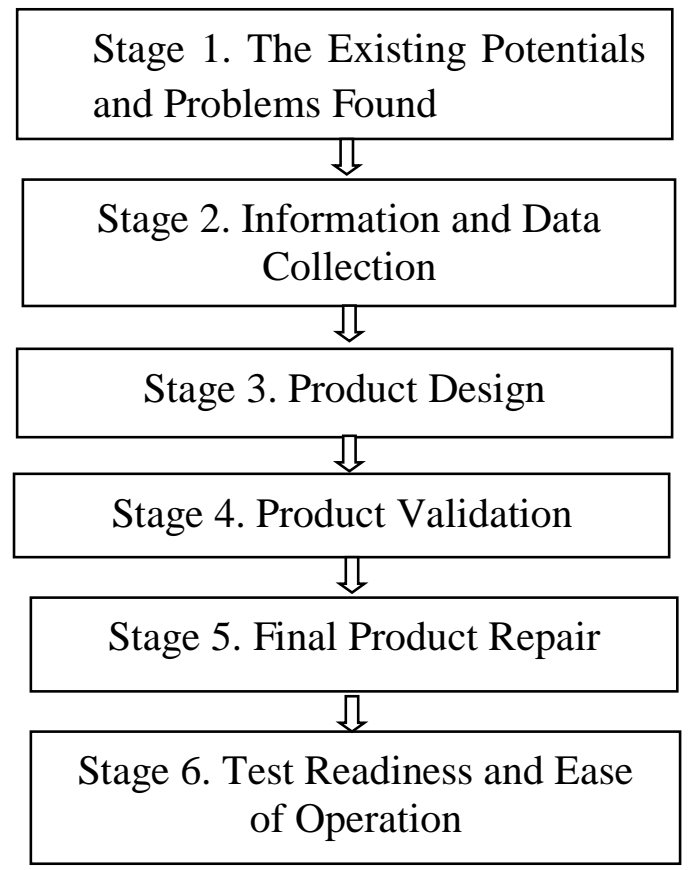

Figure 1. Electronic school books interactive production steps

Data analysis was done through the validation test and readability test and the practicality of operation. Validity test was done by using a design test and material test. Material tests and design tests were carried out by experts to evaluate the content or material and design of the interactive electronic school book on black body radiation material. The material and design expert tests were carried out by two physics education lecturers with a Doctoral degree, namely Dr. Abdurahman, M.Sc. and the chief lecturer; Drs. I Dewa Putu Nyeneng, M.Sc. In addition, the material and design expert tests were also conducted by three high school physics teachers who were certified as educators namely Levi Prihata, S.Pd., Joko Purwanto, S.Pd., and Zulimah, S.Pd. the assessment of design and the material were done using a questionnaire.

This assessment questionnaire had four answer choices according to the content of the statement, namely score 4 "Very Appropriate", score 3 "Appropriate", score 2 "less appropriate" and score 1 "inappropriate". So that the total 
assessment score can be calculated using the following formula:

$$
\frac{\text { Number of scores on the instrument }}{\text { The highest total score value }} \times 4
$$

Converting score into value statement can be seen in Table 1 and Table 2 .

Table 1. Conversion assessment score into a value statement quality

\begin{tabular}{cl}
\hline Average Score & \multicolumn{1}{c}{ Category } \\
\hline $3,26-4,00$ & Very Appropriate \\
$2,51-3,25$ & Appropriate \\
$1,76-2,50$ & Less Appropriate \\
$1,01-1,75$ & Inappropriate \\
\hline
\end{tabular}

Feasibility and practicality of operation tests were performed by the students using a questionnaire. The product was tested on seven students of the twelfthgrade students of Senior High School 16 Bandar Lampung consisted of three males and four females. Seven students were given the same treatment, namely learning using the developed product. Then the students were asked to complete the feasibility and practicality instrument. This assessment questionnaire had four answer choices according to the content of the statement, namely score 4 "Very Good" and "Very Easy", score 3 "Good" and "Easy", score 2 "Good Enough" and "Easy Enough", and score 1 "Not Good" and "Not Easy".

Table 2. Conversion assessment score into a value statement quality

\begin{tabular}{clc}
\hline Average Score & Category & Category \\
\hline $3,26-4,00$ & Very Good & Very Easy \\
$2,51-3,25$ & Good & Easy \\
$1,76-2,50$ & Good Enough & Easy Enough \\
$1,01-1,75$ & Not Good & Not Easy \\
\hline
\end{tabular}

\section{RESULTS AND DISCUSSION}

The result of this research development is an interactive electronic school book based on LCDS on black-body radiation as self-instructional materials to foster students' critical thinking skills. The Basic Competency used is applying quantum concepts in explaining blackbody radiation, photoelectric effects, and scattering of physics material in high school on the twelfth-grade students."

In detail, the results of each stage of the development procedure were carried out as follows.

\section{The Existing Potentials and Problems Found}

Potentials based on a need's analysis conducted and observations showed that in schools there are facilities such as LCD and computers that can be used and the students' ability to operate the computer. The problems found showed that many students did not really understand the concept in learning physics because of the lack of media to support the learning. Based on the result of questionnaire analysis the students' needs are listed in Table 3.

Table 3. Results of the analysis of the needs of students

\begin{tabular}{cl}
\hline Percentage & \multicolumn{1}{c}{ Criteria } \\
\hline $45,5 \%$ & Student' Worksheet \\
$48,5 \%$ & Virtual laboratory \\
$75,8 \%$ & Experiments directly \\
$33,3 \%$ & Video \\
$39,4 \%$ & Printed books \\
$24,2 \%$ & Interactive electronic \\
& book \\
\hline
\end{tabular}

Based on the potentials and problems found in the field in the needs analysis, the researcher felt the need to develop an interactive electronic school book that contains material, image, video, animation, simulation, discussion questions, and interactive tests.

\section{Collection of Information}

Information obtained from the literature read directly from books, journals, articles, and accessed via the Internet. In addition, the distribution of the questionnaire of needs analysis and material component questionnaire were also carried out. The questionnaire was given to several lecturers to gather material information needed in product development. 
Based on the results of information gathering, the components that need to be developed in the interactive electronic school book on blackbody radiation materials, among others:

1) Learning materials were developed, namely the Law of Stefan-Boltzmann Law, Shifting Wien, Rayleigh-Jeans Law, and the hypothesis of quantum Planck to emphasize the transition material the failure of classical physics in discussing the microscopic material towards the study of modern physics and displays a graph of the StefanBoltzmann law, Wien shift law, and the Rayleigh-Jeans Law.

2) Animations that need to exist in the interactive electronic school book on black-body radiation material is radiation that enters the enclosed space cannot get out again and discoloration on the metal at a given heat continuously. While the simulation needs to exist in the interactive electronic school book on blackbody radiation material is to determine the wavelength and intensity of radiation is affected by the surface temperature.

3) The examples, assignments and interactive tests for each sub-material displayed.

\section{Product Design}

The interactive electronic school book was developed using the LCDS 2.8 program, Microsoft power point 2010, Macromedia Flash 8, and ispring quiz maker. The design of interactive electronic school book development in this research was as follows; (1) Covers containing material titles, blackbody radiation illustrations, developer names, authors' names, and levels of schools; (2) Instructions containing instructional manual and instructions for using interactive electronic school book; (3) Basic competence; (4) Indicators; (5) Learning Objectives; (6) Materials containing images, phenomena, animations, simulations, initial questions, and material presentation and examples of questions; (7) Interactive Test; (8) Reference list; (9) Glossary.
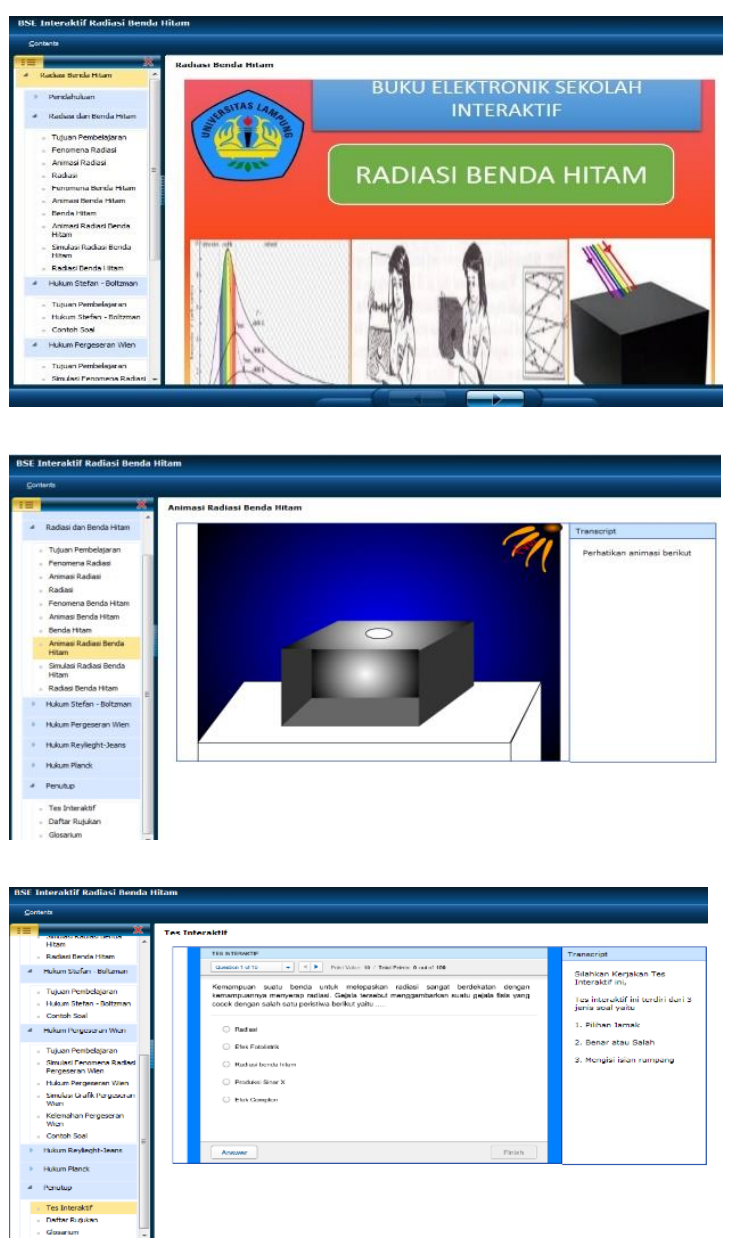

Figure 2. Interactive Electronic School Book Display

\section{Product Validation}

After the initial product was finished, the next step was to test the validity by a team of experts consisting of material experts and design experts. Material experts examined whether the content component of the interactive electronic school book was in accordance with the value of the quality set by the Center for Curriculum and Books. While the design experts assess suitability indicators such as component design on the cover, suitability of the content design component of the book and the overall packaging of the book design. 
The results of material validation and design assessment can be seen in table 4 and table 5 .

Table 4. Results of expert validation toward the product's material

\begin{tabular}{|c|c|c|c|}
\hline No. & Aspect & Score & Category \\
\hline 1. & $\begin{array}{l}\text { The aspect of } \\
\text { Conformity }\end{array}$ & 3.35 & $\begin{array}{c}\text { Very } \\
\text { Appropriate }\end{array}$ \\
\hline 2. & $\begin{array}{l}\text { Learning } \\
\text { Material } \\
\text { Accuracy }\end{array}$ & 3.28 & $\begin{array}{c}\text { Very } \\
\text { Appropriate }\end{array}$ \\
\hline 3. & Up-to-date & 3.3 & $\begin{array}{c}\text { Very } \\
\text { Appropriate }\end{array}$ \\
\hline 4. & $\begin{array}{l}\text { Compliance } \\
\text { Material with } \\
\text { Scientific } \\
\text { Approach }\end{array}$ & 3.5 & $\begin{array}{c}\text { Very } \\
\text { Appropriate }\end{array}$ \\
\hline
\end{tabular}

Table 5. Results of expert validation toward the product's design

\begin{tabular}{clcc}
\hline No & \multicolumn{1}{c}{ Aspect } & Score & Category \\
\hline 1. & Layout design & 3,2 & Match \\
2. & Typography & 3,4 & Very Appropriate \\
3. & $\begin{array}{l}\text { Illustrations } \\
\text { Conformity }\end{array}$ & 3,45 & Very Appropriate \\
& $\begin{array}{l}\text { interactive. } \\
\text { electronic school }\end{array}$ & 3,6 & Very Appropriate \\
book for & & \\
\hline
\end{tabular}

Based on Table 4 and Table 5 it can be seen that the feasibility of the components of the material in interactive electronic school book has met the criteria as a medium that can help teachers and students in learning black-body radiation material with reference to scientific approach, and feasibility of design within the interactive electronic school book has met the criteria as a medium that can help teachers and students in the learning process.

\section{Products Improvement}

Based on the results of expert material and design validation, suggestions were obtained. The next step was to make improvements to the product. The suggestions for improvements were that; it should have a good level of indicators, using operational verbs with the basic concept of online learning, learning objectives must be clear, presenting examples of video of radiation phenomena, and present examples of reallife radiation in the field of technology. Suggested improvements for the design; it should use a harmonic background color and availability of user instruction manual.

\section{Feasibility and Practicality}

The product was tested on seven students of twelfth grade consisting of three males and four females. This test aims to see the feasibility and practicality of operation of the product.

The results of the feasibility and practicality of operation can be seen in table 6.

Table 6. The test results

\begin{tabular}{clc}
\hline No. & \multicolumn{1}{c}{ Statement } & Score Tester \\
\hline 1. & The use of language in the interactive electronic book is easy to understand & 3.28 \\
independently & 3.28 \\
2. & Use of language in the electronic book is communicative and interactive \\
3. & Use of language in the electronic book is interactive and not causing double \\
meanings & 3.28 \\
4. & Interactive electronic books are using good sentence structure, so it is easy to \\
& understand & 3.28 \\
5. & Use of language in the interactive electronic book is appropriate & 3.14 \\
6. & Language use can encourage critical thinking \\
7. & Directive/ command/guide is easy for students to understand & 3.14 \\
8. & Question is able to facilitate students' understanding of interactive electronic books \\
9. $\quad$ Chronology of presentation is able to make the interactive electronic book easily & 3.28 \\
10. Coverage content (images, animations, simulations) is able to make the interactive & 3.28 \\
\hline
\end{tabular}


Based on the results of feasibility and practicality of operation tested on the 7 students, it can be seen that overall interactive electronic school book is good in terms of feasibility and practicality of operation so that it can be used as self- instructional materials that can explain the concept of blackbody radiation.

As for the final design of an interactive electronic school book on black-body radiation material, can be seen in figure 2

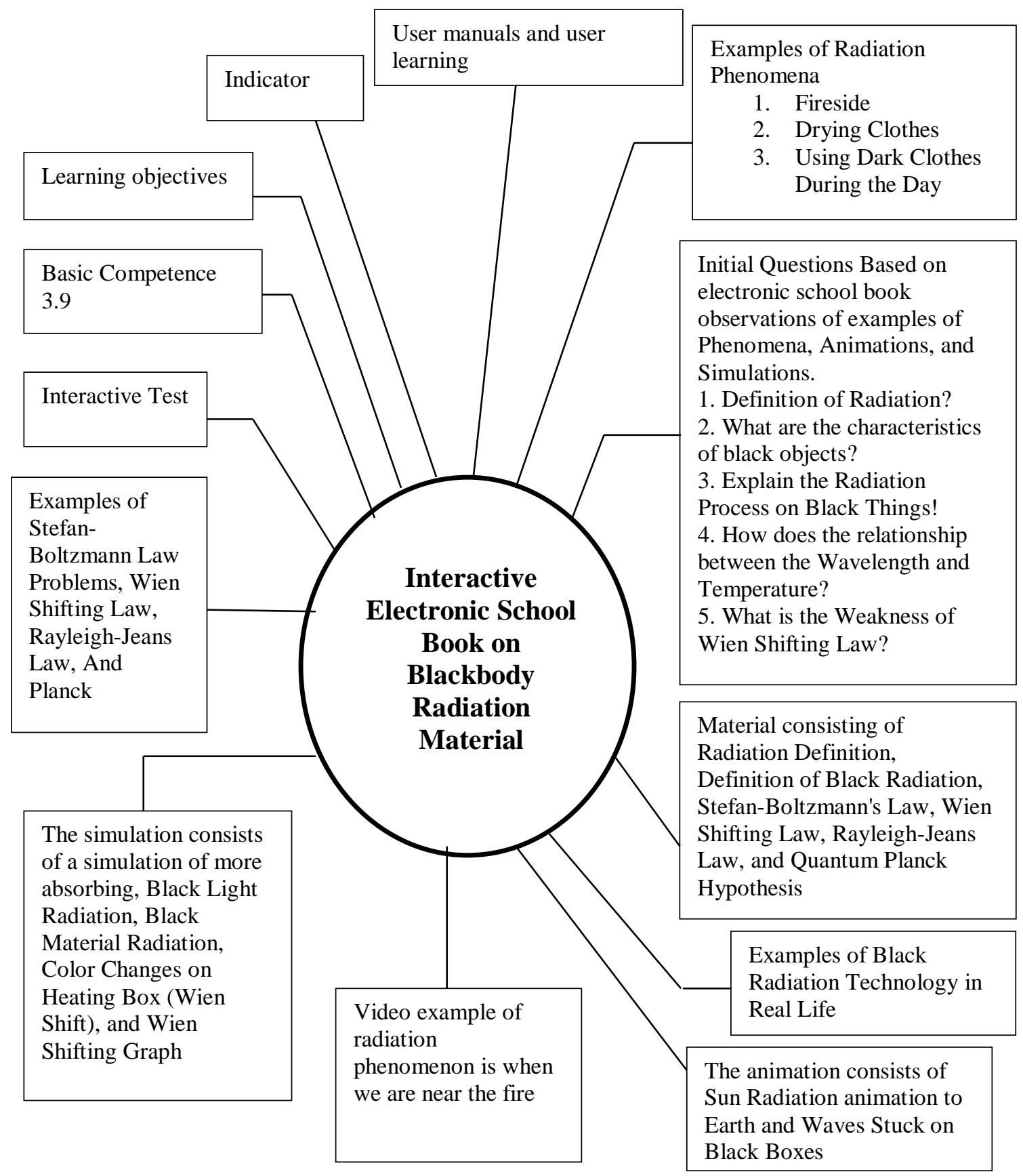

Figure 3. Interactive electronic school book structure of blackbody radiation

Discussion about the development of LCDS-based interactive electronic school book on blackbody radiation material is the appropriateness of interactive electronic school book design as selfinstructional material and foster critical thinking skills as well as product development shortcomings. 
The appropriateness of interactive electronic school book design as selfinstructional material to foster critical thinking skills

Interactive electronic school book on blackbody radiation can be used as selfinstructional materials by students. There are instructions for usage and instructions on studying using the electronic school book. The existence of instruction manuals and study instructions make it easier for students to the book as selfinstructional materials. The instruction manuals contain how to use and operate an interactive electronic school book, while the study instructions contain a way to learn. Moreover, to any existing menu in an interactive electronic school book on blackbody radiation material, there are also directives and guidance measures that facilitate student learning.

Interactive electronic school book on blackbody radiation material can also be used to foster critical thinking skills. The use of interactive multimedia is more efficient in learning than the conventional media (Gerven, Paas, Van, Hendriks, \& Schmidt, 2003). There is some content on the interactive electronic school book on blackbody radiation material that can improve critical thinking skills, among other the phenomenon example of pictures and video, the original question, animation, simulation, and exposure of the material and interactive tests. The use of multimedia in the electronic school book can improve critical thinking skills. Students tended to view the integrating Interactive Whiteboard (IWB) learning environment as providing more opportunities for them to think and to perform inquiry learning, and that the digital teaching materials presented using IWB were not only interesting and simple to operate, but also more challenging and stimulating (Yang, Wang, \& Chiu, 2015). Interactive multimedia Android-System game can improve critical thinking skills on the effective category which is proven through the observations (Wardani, Lindawati, \& Kusuma, 2017).

The example content of blackbody radiation phenomena in the form of pictures and video will help students to identify and characterize a phenomenon of blackbody radiation so that students are able to hypothesize a definition. This is appropriate with the critical thinking indicators defining the term and considers a definition. Students who are using elearning contained interactive video gain better learning outcomes significantly and gain confidence level higher than students who used the conventional media (Zhang, Zhou, Briggs, \& Nunamaker, 2006).

Furthermore, there are several animation and simulation in an interactive electronic school book to foster critical thinking skills. The animations and simulations will help the students to process and analyze an event so that they are able to identify and analyze the arguments. This is appropriate with the critical thinking indicators defining the term and consider a definition and identify assumptions. The existence of a significant impact of online learning for transferring knowledge-based animation and student motivation (Rosen, 2009). The simulation is an efficient and effective way to learn complex and dynamic concepts. The efficiency gained by reducing the time required to achieve the objectives in learning and effectiveness gained by achieving better results in the task being studied (Parush, Hamm, \& Shtub, 2002).

After the animation and simulation displayed on interactive electronic school book, then there is the initial question that refers to the answers based on the observations on animation or simulation. The initial inquiry will help the students in arguing or answering questions based on their prior knowledge. By giving a problem, students become more creative in thinking, and they can be challenged so that it can grow great curiosity to solve 
problems (questions) encountered in the learning process. A statistically significant relationship was found between the critical thinking dispositions and the problem-solving skills of students (Ozyurt, 2015). Physics students' learning outcome increases due to the problems that students are required to actively think (Hartini, Kusdiwelirawan, \& Fitriana, 2014). The application of the ProblemBased Learning model is able to increase critical thinking skills and creative action of the students (Nuswowati, Susilaningsih, Ramlawati, \& Kadarwati, 2017).

Furthermore, there is a brief exposure to the material in several sub-materials after initial questions. With the exposure of the material that contains the answer to the initial question, will assist the students in comparing the answer with the exposure of the material and the results of the electronic school book observations made. This is in accordance with indicators of critical thinking which is to consider and analyze the results of the induction argument.

There is also an interactive test at the end of the exposure of the material; the interactive tests will help students to foster their critical thinking skills. In addition, the evaluation tool simplifies the interchange of information on physics among teachers and lecturers (Morera, Arauzo-azofra, \& García-hernández, 2012). The program interactive quiz can be used to train the ability to discover physical phenomena presented in a matter that contains illustrations of physical phenomena such as interactive animations, interactive video and interactive graphics as well as feedback responses of the students and the improvement of learning outcomes (understanding) regarding the exploration of physical phenomena after the use of interactive quizzes.

\section{Advantages and Disadvantages of the Developed Product}

Interactive electronic school book based on LCDS has some advantages and disadvantages. The advantages namely blackbody radiation material classified as an abstract material can be visualized through illustrations, animations, simulations, video learning, and can be operated offline on your laptop or computer. So it becomes a book that is attractive and desirable by the user and easy to use. While the weaknesses are it is not possible to add an equation because there is no Microsoft Equation. So to overcome the shortcomings the equation or text must be changed into jpg format or another supporting format, the use of other applications such as PowerPoint, learning videos cannot be played before first installing Microsoft Silverlight, and to open the Interactive electronic school book should be using the Mozilla support.

\section{CONCLUSION AND SUGGESTION}

Based on the results of research and discussion, it can be concluded that the developed product is valid as selfinstructional materials to foster critical thinking skills that contain material in the form of text, images, animations, simulations, and interactive tests. The score test about the subject matter from the subject material expert is 3.36 (very appropriate), and from the design, the expert is 3.45 (very appropriate). Moreover, the feasibility gained a mean score of 3.23. The practicality of operation gained a mean score of 3.28 so that it can be operated independently.

This research has limitations. Namely, this product has not been tested in the field to look for the effectiveness of this interactive electronic school book. For further development, it is advisable to do a test on the actual student. This testing can be done by comparing the results of learning and critical thinking skills class that uses the interactive electronic school book with the class using the printed book. 
Besides that, the composition of the image, animation, simulation, and selection of diction in the prologue is expected to be packaged more interestingly so that it can motivate students more in using this book.

\section{ACKNOWLEDGMENTS}

The authors highly appreciate the subject material expert and design expert for constructive suggestions and feedback on the development of interactive electronic school book on black-body radiation material. Thank you to the Research Institute and Community Service of Lampung University who has funded this research

\section{REFERENCES}

Alter, F. (2009). Understanding The Role Of Critical And Creative Thinking In Australian Primary School Visual Arts Education. International Art in Early Childhood Research Journal, 1(1), 1-12.

Baker, M., \& Pomeroy, C. (2001). Relationships Between Critical And Creative Thinking. Journal of Southern Agricultural Education Research, 51(1), 173-188.

Depdikbud. (2013). Permendikbud No. 81A Tentang Implementasi Kurikulum Pedoman Umum Pembelajaran, 201-209.

Gerven, P. W. M. Van, Paas, F., Van, J. J. G., Hendriks, M., \& Schmidt, H. G. (2003). The Efficiency Of Multimedia Learning Into Old Age. British Journal of Educational Psychology, 73, 489-505.

Hartini, T. I., Kusdiwelirawan, A., \& Fitriana, I. (2014). Pengaruh Berpikir Kreatif Dengan Model Problem Based Learning (PBL) Terhadap Prestasi Belajar Fisika Siswa Dengan Menggunakan Tes Open Ended. Jurnal Pendidikan IPA Indonesia, $3(1), 8-11$.

Jagodzin, P., \& Wolski, R. (2015). Assessment Of Application Technology Of Natural User
Interfaces In The Creation Of A Virtual Chemical Laboratory. J Sci Educ Technol, 24(1), 16-28. https://doi.org/10.1007/s10956-0149517-5

Mahbub, M. Z., Kirana, T., \& Poedjiastoeti, S. (2016). Development Of Stad Cooperative Based Learning Set Assisted With Animation Media To Enhance Students' Learning Outcome in MTS. Jurnal Pendidikan IPA Indonesia, 5(2), 247-255. https://doi.org/10.15294/jpii.v5i2.60 04

Morera, L., Arauzo-azofra, A., \& Garcíahernández, L. (2012). Analysis Of Online Quizzes As A Teaching And Assessment Tool. Journal of Technology and Science Education, 2(1), 39-45.

Mutakinati, L., Anwari, I., \& Yoshisuke, K. (2018). Analysis Of Students' Critical Thinking Skill Of Middle School Through Stem Education Project-Based Learning. Jurnal Pendidikan IPA Indonesia, 7(1), 5465.

https://doi.org/10.15294/jpii.v7i1.10 495

Nuswowati, M., Susilaningsih, E., Ramlawati, \& Kadarwati, S. (2017). Implementation Of Problem-Based Learning With Green Chemistry Vision To Improve Creative Thinking Skill And Students' Creative Actions. Jurnal Pendidikan IPA Indonesia, 6(2), 221-228. https://doi.org/10.15294/jpii.v6i2.94 67

Nwineh, L., \& Okwelle, P. (2018). Acquisition Of Practical Skills In Domestic Electrical Installation: Computer Simulation Versus Demonstration Approach. Journal of Technical Education and Training, 10(1), 45-55.

Ongardwanich, N., Kanjanawasee, S., \& Tuipae, C. (2015). Development of 
21 st Century Skill Scales as Perceived by Students. Procedia Social and Behavioral Sciences, 191, 737-741.

https://doi.org/10.1016/j.sbspro.2015 .04 .716

Ozyurt, O. (2015). Examining The Critical Thinking Dispositions and The Problem Solving Skills of Computer Engineering Students. Eurasia Journal of Mathematics, Science \& Technology Education, 11(2), 353-361. https://doi.org/10.12973/eurasia.201 5.1342a

Parush, A., Hamm, H., \& Shtub, A. (2002). Learning Histories in Simulation-Based Teaching: The Effects on Self- Learning and Transfer. Computers \& Education, 39, 319-332. https://doi.org/10.1016/S03601315(02)00043-X

Rante, P., Sudarto, \& Ihsan, N. (2013). Pengembangan Multimedia Pembelajaran Fisika Berbasis AudioVideo Eksperimen Listrik Dinamis Di SMP. Jurnal Pendidikan IPA Indonesia, 2(2), 203-208.

Rosen, Y. (2009). The Effects of An Animation-Based On-Line Learning Environment on Transfer of Knowledge And on Motivation for Science And Technology Learning. J. Educational Computing Research, 40(4), 451-467. https://doi.org/10.2190/EC.40.4.d

Sugiyono. (2011). Metode Penelitian Kuantitatif dan Kualitatif R\&D, 9, 53-57.

Wardani, S., Lindawati, L., \& Kusuma, S. (2017). The Development Of Inquiry By Using Android-System-Based Chemistry Board Game To Improve Learning Outcome And Critical Thinking Ability. Jurnal Pendidikan IPA Indonesia, 6(2), 196-205. https://doi.org/10.15294/jpii.v6i2.83 60
Wartono, W., Hudha, M. N., \& Batlolona, J. R. (2018). How Are The Physics Critical Thinking Skills of The Students Taught by Using InquiryDiscovery Through Empirical and Theorethical Overview? EURASIA Journal of Mathematics, Science and Technology Education, 14(2), 691697.

https://doi.org/10.12973/ejmste/8063 2

Wiyono K., Liliasari, Setiawan, A., Paulus, C. . (2012). Model Multimedia Interaktif Berba-sis Gaya Belajar Untuk Meningkatkan Pengua $\neg$ saan Konsep Pendahuluan Fisika Zat Padat, 2(2), 264-275.

Yang, K., Wang, T., \& Chiu, M.-H. (2015). Study The Effectiveness of Technology-Enhanced Interactive Teaching Environment on Student Learning of Junior High School Biology. Eurasia Journal of Mathematics, Science \& Technology Education, 11(2), 263-275. https://doi.org/10.12973/eurasia.201 5.1327a

Yilmaz, R. M., Baydas, O., Karakus, T., \& Goktas, Y. (2015). An Examination of Interactions in A Three-Dimensional Virtual World. Computers \& Education, 88, 256-267. https://doi.org/10.1016/j.compedu.201 5.06 .002

Zhang, D., Zhou, L., Briggs, R. O., \& Nunamaker, J. F. (2006). Instructional Video in E-Learning: Assessing The Impact of Interactive Video on Learning Effectiveness. Information \& Management, 43, 15-27. https://doi.org/10.1016/j.im.2005.01. 004 